\title{
DÜBLIN
}

Technological University Dublin

ARROW@TU Dublin

2009-01-01

\section{Renewable Energy Resources and Technologies Applicable to Ireland}

\author{
Fergal O'Rourke \\ Technological University Dublin, fergal.orourke@tudublin.ie \\ Fergal Boyle \\ Technological University Dublin, fergal.boyle@tudublin.ie \\ Anthony Reynolds \\ Technological University Dublin, anthony.reynolds@tudublin.ie
}

Follow this and additional works at: https://arrow.tudublin.ie/engschmecart

Part of the Energy Systems Commons

\section{Recommended Citation}

O'Rourke, F., Boyle, F., Reynolds, A.: Renewable Energy Resources and Technologies Applicable to Ireland. Renewable and Sustainable Energy Reviews, 2009, 13 (8), pp.1975-1984. doi:10.1016/j.rser.2009.01.014

This Article is brought to you for free and open access by the School of Mechanical and Design Engineering at ARROW@TU Dublin. It has been accepted for inclusion in Articles by an authorized administrator of ARROW@TU Dublin. For more information, please contact arrow.admin@tudublin.ie, aisling.coyne@tudublin.ie, gerard.connolly@tudublin.ie.

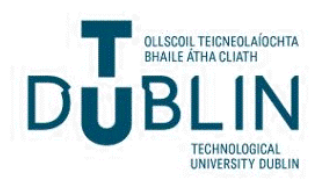




\title{
Renewable Energy Resources and Technologies Applicable to Ireland
}

\author{
Fergal O Rourke*, Fergal Boyle, Anthony Reynolds \\ Department of Mechanical Engineering, \\ Dublin Institute of Technology, Bolton Street, Dublin 1, Ireland
}

\begin{abstract}
The energy consumed in Ireland is primarily achieved by the combustion of fossil fuels. Ireland's only indigenous fossil fuel is peat; all other fossil fuels are imported. As well as fossil fuels continually becoming more expensive, their use as an energy source also has a negative impact on the environment. Ireland's energy consumption can be separated into 3 divisions; transportation, electricity generation and heat energy. Ireland however has a vast range of high quality renewable energy resources. Ireland has set a target of 33\% of its electricity will be generated from renewable sources by 2020[1]. The use of biomass, wind and ocean energy technologies is expected to play a major part in meeting this target. The use of renewable energy technologies will assist sustainable development as well as being a solution to several energy related environmental problems. This paper presents the current state of renewable energy technologies and potential resources available in Ireland. Considering Ireland's present energy state, a future energy mix is proposed.
\end{abstract}

Keywords: Renewable energy, Ireland, sustainability

\section{Contents}

Introduction 2

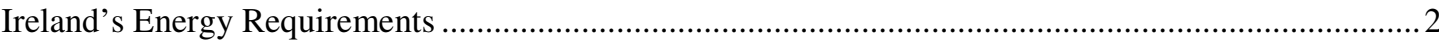

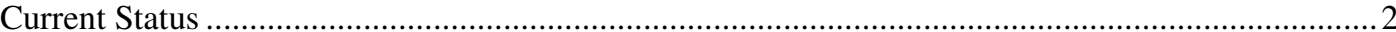

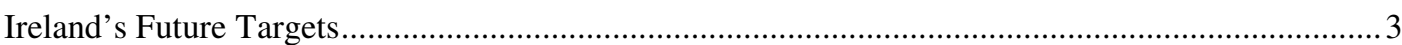

Drivers for Deployment of Renewable Energy Technologies in Ireland .................................... 4

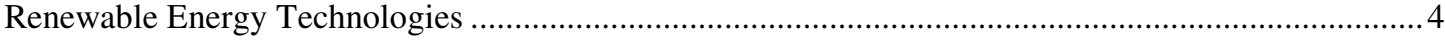

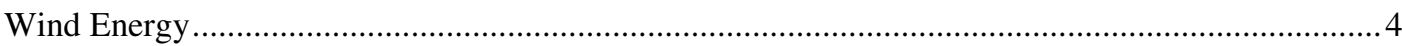

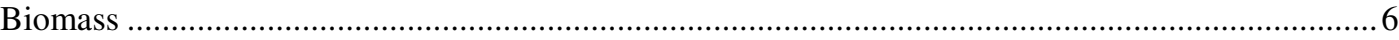

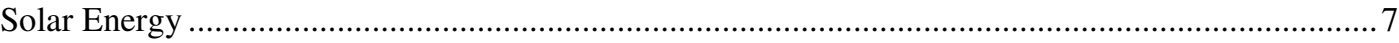

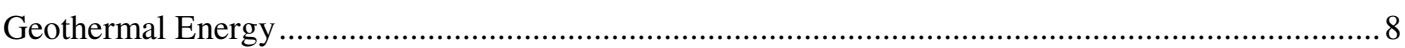

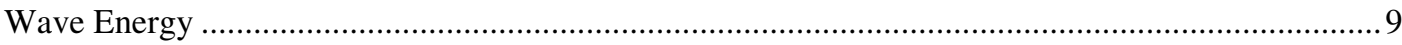

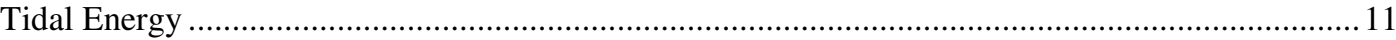

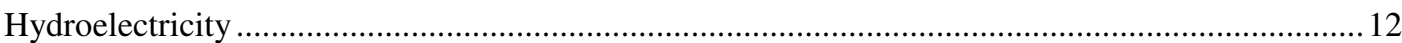

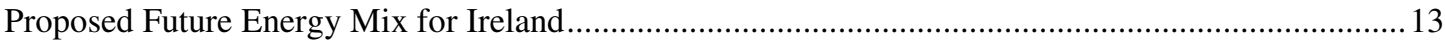

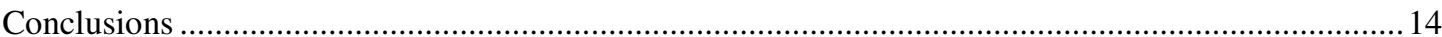

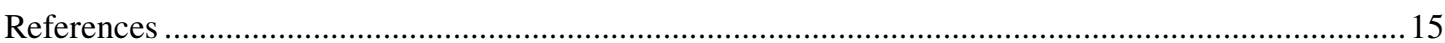

* Corresponding author: Tel: 003531402 2978; Fax: 0035314023991

E-mail address: fergal.orourke@dit.ie 


\section{Introduction}

The annual world primary energy consumption increased by $2.4 \%$ in 2007 to $11,099.3$ million tons of oil equivalent (mtoe)[2]. The majority of this energy consumption is obtained by combusting fossil fuels such as oil (3952.8 mtoe), natural gas (2637.7 mtoe) and coal (3177.5 mtoe)[2]. Nuclear energy (622 mtoe) and hydroelectricity (709.2 mtoe) only accounted for a small part of the overall primary energy consumption. In 2007 the global share of energy from fossil fuels was $88 \%$ of the total primary energy consumption. This global dependence on combusting fossil fuels to meet the growing energy demand is causing several energy related issues, including environmental problems, security of energy supply and cost competitiveness.

There are several factors that must be taken into account when evaluating energy sources, such as remaining reserves, stability of prices, geographical distribution, production shares, commercial status, reliability and environmental effects[3]. In considering these factors, renewable energy technologies look promising and are rapidly becoming more appealing. The development of renewable energy technologies in Ireland is influenced by the Irish government energy policy. Since renewable energy sources are indigenous and non-polluting, they can deal with both security of supply concerns and environmental issues.

Ireland has committed to meet the various targets set by the EU on renewable energy, energy efficiency and climate change. There are many different sources of renewable energy available to Ireland, including wind, solar, geothermal, biomass, tidal, wave and hydro. In terms of the energy consumption from renewable energy technologies in Ireland, hydroelectricity has been exploited for a long time with wind recently coming of age.

\section{Ireland's Energy Requirements}

\subsection{Current Status}

The majority of Ireland's energy is consumed by electricity generation, heat generation and transportation. Ireland is heavily dependant on fossil fuel imports to meet these energy requirements. Ireland's energy import dependence reached 91\% in 2006[4], making Ireland the most import dependant country in the EU. Peat is Ireland's only indigenous fossil fuel source; all other fossil fuel sources are imported[5]. Ireland's energy consumption has increased significantly since the early 1990's.

In 2006 energy consumption in Ireland reached 13.011 mtoe, with the use of fossil fuels accounting for $96 \%$ of the energy consumed[4]. The transport sector is Ireland's largest energy consumption sector with a share of $41.5 \%$ of the final energy consumption, followed by the residential and industrial sectors with shares of $23 \%$ and $20.6 \%$ respectively. The agricultural and services sectors are the remaining two energy consumption sectors with shares of $2.5 \%$ and $12.4 \%$ respectively[5]. The consumption of energy in the transport sector has increased by $167 \%$ over the period $1990-2006$. In 2006, energy use in the industrial and residential sectors increased at an annual rate of $1.7 \%$ and $1.2 \%$ respectively.

In 2006, electricity generation accounted for $32 \%$ of the primary energy consumption[5]. The efficiency of electricity supply increased to $41.3 \%$ in 2006 from $40.3 \%$ in 2005 . The coming on stream of two combined cycle gas turbines (CCGT), the first of these in August 2002 with a power capacity of $392 \mathrm{MW}$ and the second in November 2002 with a power capacity of $343 \mathrm{MW}$ and with the closure of old peat power plants, resulted in a sharp increase in electricity generation efficiency from $35 \%$ in 2002 to $40 \%$ in 2004[5]. In 2006 the use of renewable energy technologies accounted for $8.6 \%$ of the electricity consumption. Natural gas consumption increased by $18 \%$ resulting in a reduction of $13 \%$ in the use of peat for electricity generation[4]. 


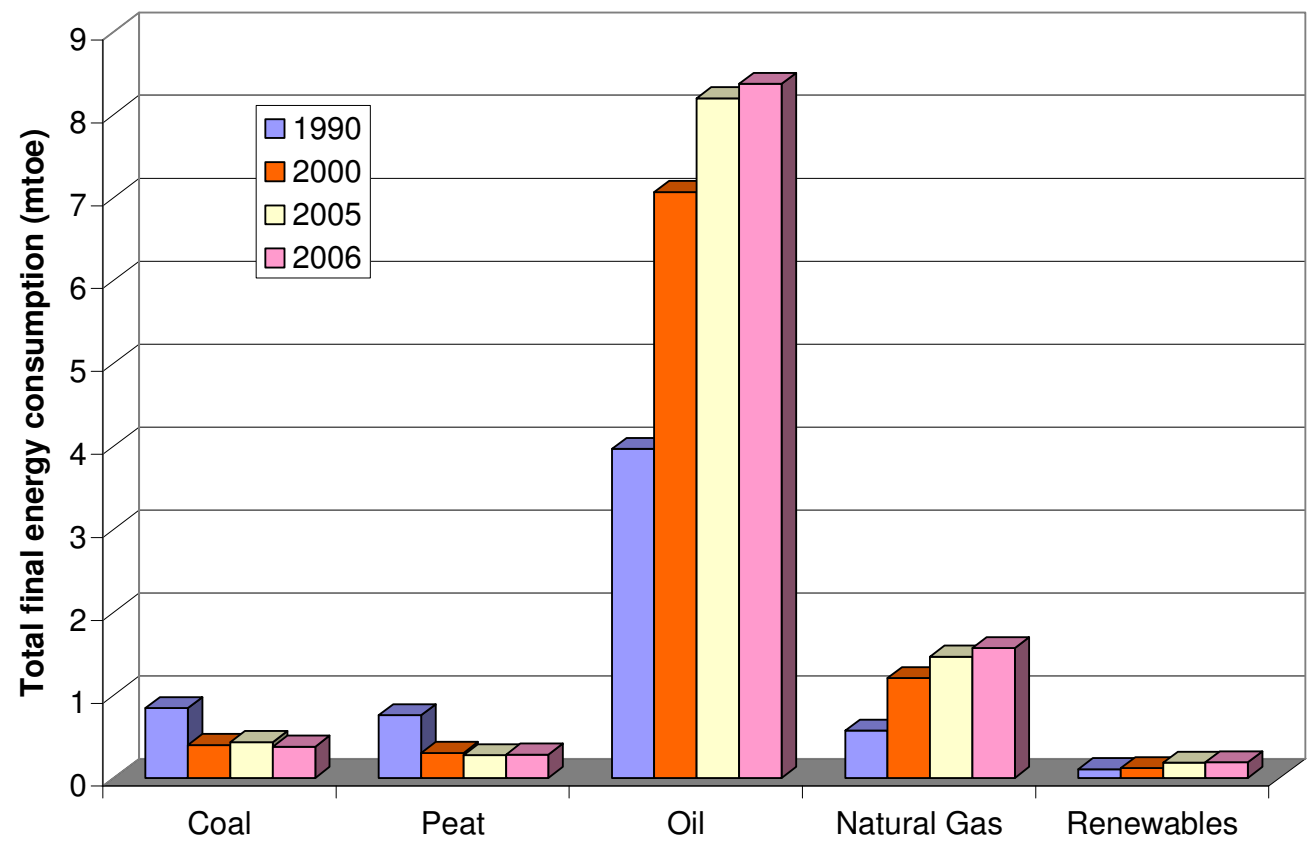

Figure 1. Total final energy consumption in Ireland by fuel[4].

Figure 1. illustrates the final consumption of each fuel over the period 1990 - 2006. In 2006 natural gas experienced the highest growth by fuel in Ireland, increasing by an annual rate of $7.1 \%$ in comparison to the annual average increase of $4.3 \%$ between the years 2000 - 2005. This growth in the use of natural gas is a result of its use as a replacement for other fuels to generate electricity and increased use in the industrial and residential sectors. Oil use alone increased by an incredible $111 \%$ since 1990 with a consumption growth of $2.1 \%$ in 2006 . The use of coal has decreased significantly since 1990 , from a final energy consumption share of $11.6 \%$ in 1990 to $2.9 \%$ in 2006. In 2006 coal consumption decreased by an annual rate of $13 \%$, although the use of coal to generate electricity has remained unchanged since 1990. Peat consumption experienced an increase of 3.8\%; however the consumption of peat has decreased by $62.5 \%$ over the period $1990-2006$. The use of renewable energy technologies increased by $2.5 \%$ in 2006; however the energy consumption share percentage of renewable energy has decreased from $1.5 \%$ to $1.4 \%$ over the period $1990-2006$. The majority of the growth in the use of renewable energy technologies in Ireland was achieved in the residential sector and with the use of wind energy to generate electricity.

\subsection{Ireland's Future Targets}

An Irish government energy white paper entitled Delivering a Sustainable Energy Future for Ireland was published by the Department of Communications, Marine and Natural Resources on the $12^{\text {th }}$ March 2007. The Irish government white paper set out the goal to deliver a sustainable energy future for Ireland. The paper is driven primarily by the challenge of a secure energy supply and the prevention of climate change. The energy white paper sets out the Irish government's energy action plans towards 2020 including:

- Actions to ensure security of energy supply.

- Actions to promote the sustainability of energy supply and use.

- Actions to enhance the competitiveness of energy supply.

The energy market in Ireland can be separated into 3 divisions: electricity generation, thermal energy and transportation. With regard to renewable energy the following targets were set:

- $\quad 15 \%$ of Ireland's electricity consumption will be generated from renewable sources by 2010 , and $33 \%$ generated from renewable sources by 2020.

- $500 \mathrm{MW}$ of ocean energy capacity and $800 \mathrm{MW}$ of Combined Heat and Power (CHP) with an emphasis on biomass will be installed by 2020 . 
- $\quad 30 \%$ biomass co-fired at the state owned peat power plants by 2015 .

The Irish government energy white paper also sets out the goal to increase the electricity transfer capacity to $680 \mathrm{MW}$ between the north and south of Ireland with a second interconnector. The investment in an interconnector from east to west of Ireland with a capacity of $500 \mathrm{MW}$ will assist in the development of renewable electricity generation[1].

In terms of environmental targets, the National Climate Change Strategy 2007-2012 was published by the Department of the Environment, Heritage and Local Government on the $2^{\text {nd }}$ of October 2007 setting out measures by which Ireland will meet its Kyoto Protocol 2008 - 2012 commitment, and also setting out measures for the post Kyoto period. The report estimates an annual emissions reduction of 1.47 million tonnes of $\mathrm{CO}_{2}$ will be achieved with the target of $15 \%$ renewable electricity by 2010 , and an annual emissions reduction of 3.26 million tonnes with $33 \%$ renewable electricity by 2020 [1].

\subsection{Drivers for Deployment of Renewable Energy Technologies in Ireland}

There are numerous drivers and motivators for the deployment of renewable energy technologies in Ireland. Some of the drivers include:

- Security of energy supply. This can be separated into three sub-drivers. The first of these subdrivers is the fact that fossil fuels are limited geological resources. The increasing demand on fossil fuels poses a treat to energy supply. The second sub-driver deals with geopolitical issues relating to the distribution of fossil fuels. Many of the countries with high energy consumption have little or no indigenous fossil fuel resources exposing them to political issues with fossil fuel producer countries. The third sub-driver deals with economic disadvantage, including the risks associated with disruption of supply and the disadvantage on the balance of payment which is dependant on fuel price. The use of renewable energy technologies increases the security of energy supply because they generally utilise indigenous resources. Energy from renewable technologies will contribute towards a sustainable energy future.

- Environmental concerns. The use of renewable energy technologies as a replacement for fossil fuel energy systems offers a lower lifecycle impact in reducing greenhouse gas emissions. However the use of renewable energy technologies may also have negative effects on the environment, such as visual impacts and wild life concerns.

- High and fluctuating fossil fuel prices. These are a major driver for the competitiveness and utilisation of renewable energy technologies. Since 2006 the prices of fossil fuels, and in particular oil prices, have increased significantly. It is predicted that fuel prices will not increase greatly over the forthcoming decades, although fluctuations may increase. These price fluctuations may provide an essential driver for investments in renewable energy technologies.

- Technology development and business perspectives. These are likely to become an important driver for governments and industries to invest in renewable energy technologies. It is essential to increase $R \& D$ if countries want to maintain competitiveness in global markets and increase employment.

- Agricultural, rural and social issues. Policies can become important drivers for the utilisation of biomass technologies. Energy crops will aid rural development as it provides a market outlet for agriculture. Wind and solar technologies can be used in areas of sparse population as these technologies do not need grid connection.

\section{Renewable Energy Technologies}

\subsection{Wind Energy}

\subsubsection{Technology status}

Wind electricity generation systems convert wind energy into electricity with the use of wind turbines. The kinetic energy in wind is converted into mechanical energy, which is then converted into electrical energy.

Wind turbines fall into two basic categories:

- Horizontal axis wind turbines (the rotating shaft rotates horizontal to the ground). 
- Vertical axis wind turbines (the rotating shaft is vertical to the ground).

Horizontal axis wind turbines with 3 rotor blades are Ireland's most commonly used wind turbines. The airfoil type rotor blades generate aerodynamic lift when the wind stream passes over them. The rotating shaft is connected to a gear box which alters the rotational speed to a quicker and more suitable rotational speed to drive a generator. The ideal operating wind speed for these wind turbines is approximately $12-14 \mathrm{~m} / \mathrm{s}[6]$. At this wind speed a maximum electricity output is achieved. The horizontal axis wind turbines are separated into 3 different technology types. The first type is constant speed turbines, which run at one rated speed regardless of wind speed. This type of wind turbine is cheap and robust, but is prone to noise generation and mechanical stress. The second type is the variable speed double feed induction generator; it offers greater aerodynamic efficiency because it runs at variable speeds. This reduces both the mechanical stress on the gearbox and the noise generation. The third type is the variable speed direct drive turbine. It operates without the use of a gearbox and has the most expensive capital investment cost.

The power ratings of the most common wind turbines vary from $750 \mathrm{~kW}$ to $2.5 \mathrm{MW}$. The rotor diameter of these turbines ranges from 48 metres to 80 metres[6]. Ireland has one offshore wind farm consisting of 7 wind turbines each rated at $3.6 \mathrm{MW}$ located off the coast of Arklow. Wind turbines with a power capacity of $5 \mathrm{MW}$ are currently in use with the improvement in wind turbine technology[6].

\subsubsection{Market status}

As of 2007 Ireland had approximately 794.5 MW of installed wind capacity, consisting of 1 offshore and 35 onshore wind energy sites[7]. Wind energy has shown exceptional growth, increasing from a capacity of 215 MW in 1992[7]. The market has become larger and more stable. Currently the cost of electricity generated from wind is similar to the cost of electricity generated from fossil fuels[6]. The cost of wind electricity generation is dependant on many factors including location, wind speeds and electrical grid connections which differ from one location to another.

As of 2006 the cost of electricity generated from wind according to an energy paper published by the Department of Communications, Marine and Natural Resources, entitled Bioenergy Action Plan for Ireland, varied from 5.7 cent per kilowatt hour (large wind energy $>5 \mathrm{MW}$ ) to 5.9 cent per kilowatt hour (small wind energy $<5 \mathrm{MW}$ )[8].

\subsubsection{Resource}

Ireland has exceptional wind energy resource with an estimated technical resource of 613TWh per year[9] of which Ireland currently utilises $2.8 \mathrm{TWh}$, equivalent to less than half a percent of the estimated technical resource[10]. Wind is intermittent and unpredictable in nature, challenging the integration of wind turbines into the electricity system. The wind energy resource in Ireland is four times that of the European average[7]. The electricity output of a wind turbine is dependant on wind speed, and is proportional to the wind speed cubed[11]. Therefore location of wind farms is important as electrical output is dependant on location. On a calm day the possibility of no electricity generation from all wind farms is very small, but because of this possibility, a back up energy supply is needed from another energy source. The use of energy storage technologies, such as batteries and hydrogen are still expensive. The use of these technologies would mean electricity would be available when needed, as it is not always the case that maximum production occurs at times of maximum consumption.

\subsubsection{Barriers}

The major issues restricting the development of wind energy include:

- Lack of robust technical information has led to opposition to wind farms being developed in certain areas.

- Environmental concerns including noise, effect on birds, visual impact, electromagnetic interference and shadows.

- The financial incentives from the Irish government to support renewable energy development are inadequate.

- Grid connection and access is not fairly provided causing a major problem for the development of wind energy.

- The taxes on renewable energy technologies reduce the competitiveness of the technology. 


\subsection{Biomass}

\subsubsection{Technology status}

Biomass refers to dead organic materials for use as a fuel and also to plants grown specifically for fuel. These fuels, known as biofuels, can be used to reduce dependence on combusting fossil fuels for energy consumption. Fossil fuels can not be considered biomass because they contain carbon which has been out of the carbon cycle for a long time. Biomass is often referred to as a carbon neutral fuel, meaning the amount of $\mathrm{CO}_{2}$ absorbed during growth equals the $\mathrm{CO}_{2}$ released during combustion. Biomass can be divided into two main categories:

- Energy crops. These include three types of crop grown specifically for energy purposes. The first of these types is short rotation forestry, which is the production of wood fuel from fast growing trees which reach their optimum size between eight and twenty years, and include ash, popular, sycamore and willow. The second type is crops such as Hemp and Miscanthus; these are annual plants, and the use of existing farm machinery could be used for harvesting these crops. The third type is liquid biofuels energy crops such as oilseed rape, which are produced primarily as a transport fuel. The use of various conversion techniques are used to produce biodiesel, bioethanol and biomethanol.

- $\quad$ Organic residues. These can be used to produce biofuels and include forest residues (branches and tree tops), agricultural residues (slurry, manure, straw and chicken litter), wood wastes (chippings, sawdust and bark), waste vegetable oil (catering industry), tallow (animal fat), municipal solid waste (food processing waste) which can produce biogas through a process called anaerobic digestion.

Biomass can be directly combusted for electricity generation, or the material known as feedstock can be converted to fuel for different applications. The technologies used to convert the feedstock to fuel for heat and power generation are as follows:

- Gasification (pyrolysis, partial oxidation, stream reforming) converts biomass to a gas fuel, which can be used as a substitute for natural gas for combustion, or formed into hydrogen for fuel cell applications.

- Anaerobic digestion converts biomass into biogas. This process involves the breakdown of organic waste by bacteria in an oxygen free environment. This biogas can be used in standard or CHP applications. Landfill gas is also produced by the breakdown of the organic components of waste.

Biomass can be converted into different energy types, including heat, power or liquid biofuels. Currently, CHP applications using waste fuels are the most cost-effective option in terms of biopower. Co-firing biomass with coal is an option for large-scale electricity generation. Biomass gasification for large-scale electricity generation is being commercialised and will be an important cogeneration technology in the forest products industry [12].

\subsubsection{Market status}

As of 2005, Ireland's installed biomass capacity was approximately 25 MW[13]. At present, the majority of biomass used in Ireland is industrial wood wastes and is used to produce heat. Seven landfill gas projects are in commercial operation in Ireland[14]. Ireland's installed biomass capacity is below the European average of $4 \%$ of its total energy needs[15]. In 2005, 1.3 million litres of biofuels were placed on the Irish market[8]. The cost of electricity generated from biomass CHP is more expensive than that of wind energy per unit (approximately 7 cent per $\mathrm{kWh}$ )[16]. Although electricity generation from wind is less expensive, it's unlike biomass generated electricity, which has the advantage of availability on demand.

\subsubsection{Resource}

Ireland's potential to develop biomass for energy is exceptional. Ireland has the best growth climate in Europe based on Paterson's Climatic Index[17]. Ireland's land area is approximately seven million hectares, of which 4.3 million hectares are used for agriculture and roughly 710,000 hectares for forestry[8]. The largest source of wood biomass is in the national forest estate, where a potential of 0.5 million tons of wood is recoverable for energy use, with an equivalent energy value of 200,000 tonnes of oil[8]. In addition to the biomass resource, there are several by-products of farming and food processing 
which can be utilised as biofuels. These consist of animal by-products, tallow, animal manures and food by-products. It is estimated that approximately $70 \mathrm{MW}$ of electricity can be generated annually from waste biomass[14].

\subsubsection{Barriers}

The major issues restricting the development of biomass include:

- Uncertainty as to the availability of biomass resources.

- The relatively low prices of fossil fuels make biomass fuels appear non-competitive.

- The taxes on renewable energy technologies reduce the competitiveness of the technology.

- The financial incentives from the Irish government to support renewable energy development are inadequate.

\subsection{Solar Energy}

\subsubsection{Technology status}

Solar energy has extraordinary theoretical potential. Solar energy can be converted into thermal energy which can be used for space or water heating, or can be converted into electricity. Solar power refers in particular to the conversion of solar energy into electricity with the use of photovoltaics or concentrating solar technologies. Concentrating solar power technologies produce thermal energy which is used to generate electricity, where the working fluid is heated by the concentrated sunlight.

Solar photovoltaics use semiconductor devices called solar cells to convert the incident sunlight into electricity using the photovoltaic effect. These systems can be placed on buildings or on the ground. This technology produces a direct current output which can be used to charge batteries, produce hydrogen or can be converted into alternating current suitable for grid connection.

Solar collectors for heat generation fall into three basic categories:

- $\quad$ Flat plate collectors comprise of a blackened surface called an absorber plate which is placed under one or more transparent surfaces. The working fluid is contained in a tank. This tank is weatherproof and well insulated. The plate absorbs the incident solar energy as heat which is transferred to the working fluid.

- Evacuated tube collectors work in principal similar to the flat plate but each absorber and pipe are sealed in a glass tube to reduce heat loss.

- Concentrating solar collectors are usually parabolic troughs which use mirrored surfaces to concentrate the incident solar energy on an absorber containing a fluid. Solar towers work much like concentrating solar collectors but instead use flat plate collectors which direct the incident solar energy on an absorber located on a tower. This type of collector is primarily used for commercial power generating applications. It produces extremely high temperatures and is dependent on direct sunlight.

\subsubsection{Market status}

The current use of solar technologies in Ireland is best suited to low temperature application systems, such as water heating and space heating, which do not require direct sunlight. As of 2006, the capacity of solar heating installed in Ireland was 3.5 MW(th)[18]. A one square metre collector area has a power capacity of $0.7 \mathrm{~kW}(\mathrm{th})[18]$. Electricity generation from concentrating solar power needs direct sunlight; therefore this technology is not suited to the Irish climate. As of 2006, the installed photovoltaic capacity was $0.3 \mathrm{MW}[19]$. This technology is extensively used for consumer products, such as calculators and also as a good fit for applications where grid connection is too expensive (remote holiday homes, telecommunication towers, etc.).

\subsubsection{Resource}

The potential for solar heating is limited by the solar radiation available. Direct sunshine is intermittent and unpredictable in Ireland, making high temperature applications (concentrating solar power) for electricity generation impracticable. The annual average global insolation (the amount of energy reaching the surface per square metre) values for Ireland range from $2.6-3.0 \mathrm{kWh} / \mathrm{m}^{2} / \mathrm{Day}[19]$. A 
surface area of one square metre receives approximately $900-1000 \mathrm{kWh}$ of solar energy per year[20]. Electricity generation from solar technologies is not fully commercialised or competitive, and so this energy source is limited to water and space heating in Ireland.

\subsubsection{Barriers}

The major issues restricting the development of solar energy include:

- The financial incentives from the Irish government to support renewable energy development are inadequate.

- Grid connection and access is not fairly provided causing a major problem for the development of solar energy.

- Solar heating and photovoltaic systems usually require the use of a back up system in periods of high demand. This is a major problem for Ireland as energy requirements are higher in winter when there is less sun.

- Large scale power generation from photovoltaic or concentrating solar technologies may be unfeasible due to low insolation levels in Ireland.

- The taxes on renewable energy technologies reduce the competitiveness of the technology.

\subsection{Geothermal Energy}

\subsubsection{Technology status}

Geothermal energy is the heat energy stored beneath the earth's surface. This heat is supplied to the earth from two sources: the hot core of the planet and the sun. This heat energy can be used for space and water heating using geothermal heat pumps or, using hot dry rock technologies, the heat energy can be used to drive a turbine to generate electricity.

When the vast majority of this heat energy reaches the earth's surface, it is inadequate for electricity generation. However this heat energy can be accessed at certain specific locations such as fault lines or by drilling through the surface. The geothermal resources are located by geological, geochemical and geophysical exploration. These resources include hot impermeable rock masses such as granite, highly permeable hot reservoirs and highly pressured hot fluids. The most successful projects to date have bore holes sunk into water channels. This method is used at the Geysers, California[21].

Sources of hot dry rock are much more abundant throughout a large portion of the world. Electricity generation from this source utilises the especially high temperatures found in these impermeable rocks beneath the earth's surface. This process involves pumping high pressure water down bore holes into the heated area. The water travels through the high temperature area gathering heat from the rock; this hot water is then forced out the second bore hole. The hot water is then used to generate electricity using a steam turbine or a binary power plant.

A geothermal heat pump system can be used as a heating or cooling system. The earth's surface absorbs radiation from the sun much like solar collectors. The geothermal heat pump takes advantage of this constant ground temperature. The temperature of the earth several metres below the surface remain very stable, especially in Ireland due to the climate. The heat pump utilises this constant heat as a heat source in winter and as a heat sink in summer. There are several types of geothermal heat pumps, generally using water with antifreeze as the fluid. There is a variety of geothermal systems available for either residential or commercial applications, including water to water heat pumps, water to air heat pumps and hybrid heat pumps.

Geothermal heat pumps are generally for residential use. There are three common types of heat pumps used in Ireland. The most common of these is the geothermal or ground heat pump and is generally used for domestic heating. The geothermal heat pump system comprises of three main components: a heat pump, buried piping on the property and a heat distribution system. The pipes are buried vertically or in a horizontal trench near the building. The purpose of the piping is to transfer the heat to and from the ground. The heat pump is the unit that replaces the boiler on a conventional heating system.

There are several emerging technologies that could further the potential of geothermal energy. The use of hybrid systems can create more electricity without expanding the geothermal resource. Geothermal 
energy can be used with biomass, CHP, geothermal heat pumps and geopressured resources which operate on natural gas and geothermal fuel. Oil field wells could be deepened into hot zones if the wells are not deep enough to encounter hot water. The use of mixed fluids especially in the binary cycle power plants can reduce thermodynamic inefficiencies[22].

\subsubsection{Market status}

The use of geothermal energy in Ireland is limited to geothermal heat pumps, used for space heating and cooling as well as water heating. The initial capital costs of installing geothermal heat pumps is still relatively expensive in comparison to conventional systems, with a typical payback period of 8-10 years[23]. Currently no electricity is generated from geothermal sources. Generating electricity from geothermal energy such as hot rock technologies is extremely expensive due to high construction costs. The use of geothermal heat pumps takes advantage of the constant annual temperature of shallow ground. Geothermal heat pumps are an efficient technology for space and water heating in Ireland. The heat pump typically produces four units of heat for every unit of electricity used[24].

\subsubsection{Resource}

In 2004, a study was performed by the CSA group at the Cork Institute of Technology in Ireland to identify resources of geothermal energy in Ireland, create geothermal models of Ireland and to review the current status of geothermal energy in Ireland. The results concluded that geothermal heat pumps are a good option due to Ireland's climate. The study was completed using existing bore holes in the ground at different locations throughout Ireland. An increase in temperature ranging from $17^{\circ} \mathrm{C}-19^{\circ} \mathrm{C}$ was recorded in the south of Ireland and temperatures ranging from $25^{\circ} \mathrm{C}-27^{\circ} \mathrm{C}$ were recorded in the north at a depth of 500 metres below the earth's surface. At a much greater depth of 2,500 metres below the earth's surface, an increase in temperature ranging from $28^{\circ} \mathrm{C}-45^{\circ} \mathrm{C}$ were recorded in the south of Ireland and temperatures ranging from $64^{\circ} \mathrm{C}-97^{\circ} \mathrm{C}$ were recorded in the north[25]. The results from this study indicate good potential for commercial development of geothermal electricity in Ireland.

\subsubsection{Barriers}

The major issues restricting the development of geothermal energy include:

- The initial cost of geothermal energy technologies is still relatively high. As of 2008, no known feasibility studies were conducted for electricity generation from hot rock technologies in Ireland.

- Geothermal heat pumps usually require the use of a back up system in periods of high heating requirements.

- The technology requires approximately the same external ground area as the floor area of the house.

- The financial incentives from the Irish government to support renewable energy development are inadequate.

- The taxes on renewable energy technologies reduce the competitiveness of the technology.

\subsection{Wave Energy}

\subsubsection{Technology status}

Winds generated by the differential heating of the earth, travel over vast volumes of ocean water transferring energy to the water to produce waves. The size of the wave depends on the strength, duration and the unobstructed distance over which the wind blows. Offshore waves commonly have larger amplitude than nearshore or onshore waves due to greater water depth (no friction from the sea bed). The energy in the waves can be utilised to generate electricity. Wave energy devices use various conversion technologies to generate electricity. These conversion technologies make use of mechanical motion or fluid pressure to generate electricity and there are several techniques including:

- Elastomeric hose pump.

- Hydraulic devices.

- Linear electric generator. 
- $\quad$ Pump to shore.

- Hydroelectric/air turbine.

The location of the wave energy devices can be onshore, nearshore or offshore. The type of device used depends on the location. The three most common wave device types are:

- Overtopping devices. The wave usually flows over a sloped barrier to fill an artificial basin. The detained water is then piped through a water turbine to produce electricity.

- Oscillating water column. One side of the device is in open air, the other side is in water. When the water rises in the column the air is displaced. An air turbine is placed at the open end of the column to generate electricity from the air flow.

- Point absorbers. This technology generally involves the use of a buoy. The movement of the buoy can be converted into mechanical or hydraulic power.

There are considerable differences between the engineering challenges of onshore, nearshore and offshore wave devices. Offshore devices will have higher transmission costs than nearshore or onshore devices. However offshore devices should be more cost effective since the power increases with the square of the amplitude of the wave[11].

\subsubsection{Market status}

The primary market for wave energy is electricity generation. Currently there is no installed capacity in Ireland[26]. The technology, however, is currently in a developing stage. In Ireland there are 3 major wave energy device developers:

- Ocean Energy Ltd

- Wavebob Ltd

- Hydam Ltd

Each developer is at a different stage of development. Ocean energy Ltd has commenced work on the construction of their prototype which is known as the Backward Bent Duct (BBD), after a quarter scale model of the device was successful when tested in harsh ocean conditions. The BBD uses wave energy to compress air in a plenum chamber. This compressed air is expanded through an air turbine to generate electricity. Wavebob Ltd has completed tests on scale models of their device, called Wavebob. Wavebob is a point absorber device and generates power from each wave from the movement of a bob. The Wavebob prototype is currently producing electricity and is deployed on the Marine Institute/Sustainable Energy Ireland wave energy test site, which is located off the coast of Spiddal in Co. Galway[27]. Hydam Ltd has constructed a large scale model of their prototype, called McCabe Wave Pump (MWP). The MWP uses hydraulic rams to create pressurised fluid which drives a hydraulic motor and generator. The pontoons rise and fall with each wave which drives these rams. The MWP is being tested in the Shannon estuary. The target date for commercial deployment of wave devices in Ireland is from 2016 onwards[26].

\subsubsection{Resource}

Ireland has an excellent wave energy resource due to its favourable climate and location. The west coast of Ireland has the best wave energy resource in Europe with annual average power levels of 76 $\mathrm{KW} / \mathrm{m}[26]$. In 2005, a report containing an assessment of Ireland's wave energy resource was completed by Sustainable Energy Ireland entitled Ireland's Wave Energy Resource. The assessment's main objective was to identify theoretical and accessible levels of wave energy in Irish waters. The results of the study indicated that a theoretical wave resource of $525 \mathrm{TWh}$ exists in Irish waters. To put this in context, in 2006 the electricity requirement for Ireland was $27.8 \mathrm{TWh}$ per year[28]. The accessible resource was estimated as $21 \mathrm{TWh}$. This estimate considered cable length to deliver power ashore from the generators. In terms of power output, the accessible Irish wave power resource is equivalent to 2.4 GW[28]. The accessible power resource value is estimated at the current technology status; therefore improvements in technologies will result in an increase in accessible power.

\subsubsection{Barriers}

Currently there is very little experience of electricity generation from wave energy. The major issues restricting the use of wave energy include: 
- The technology is currently in a developing phase, with very little demonstration experience.

- Wave technologies must be capable of withstanding extremely harsh weather conditions. This may add to the cost of design and materials.

- Because of location the maintenance costs may be relatively high.

- Current Irish government support levels are considered quite low, providing a low return on capital investment.

- The taxes on renewable energy technologies reduce the competitiveness of the technology.

- Grid connection and access is not fairly provided which may cause a problem for the development of wave energy.

\subsection{Tidal Energy}

\subsubsection{Technology status}

The ocean tides contain energy which can be used to generate electricity. Two types of energy can be utilised from tidal movements: the first is the kinetic energy from tidal current movements and the second is the potential energy from the rise and fall of the tides. Tidal energy derives from the relative motions of the earth and moon. Tides occur due to the gravitational pull of the moon and to a lesser extent the sun. When both the earth and moon are in line, a very high tide is experienced; this is known as the spring tide. When both bodies are at $90^{\circ}$ the opposite is true; this is known as a neap tide. Tidal currents occur due to the energy dissipated by the tides. The vast majority of the tides are a mixture of either diurnal (direction change once daily) or semi-diurnal (direction change twice daily).

Tidal energy devices can be categorised into 2 types:

- Tidal barrages which make use of potential energy from the difference in head between high and low tides. They are extremely expensive to construct due to structural size. There are several different ways in which barrages operate: ebb generation, flood generation and two way generation systems. There are also double basin systems which have the advantage of adjusting the delivery period to match the requirements of the consumer.

- Tidal stream devices which make use of the kinetic energy from the moving water to drive a turbine, much like wind turbines. This technology is much less expensive than barrage technology and has become a popular prospect for generating electricity.

Tidal energy device technology is in its infancy and there have only been a small number of tidal stream prototype demonstrations. On the $26^{\text {th }}$ of May 2008 an Irish company called OpenHydro completed the connection of a $250 \mathrm{KW}$ tidal turbine to the UK national grid[29]. The first generation of devices are limited to water depths of between $10 \mathrm{~m}$ to $50 \mathrm{~m}$. The second generation devices are expected to be capable of generating electricity in waters exceeding these depths.

\subsubsection{Market status}

Tides are more predictable than both wind and solar energy. Tidal energy is similar to wave energy in that its primary market is electricity generation. Currently there is no installed capacity of tidal power in Ireland[5]. There is one major tidal energy developer in Ireland called OpenHydro. On $20^{\text {th }}$ May 2008 a company called Marine Current Turbines Ltd installed a 1.2 MW tidal stream turbine at Strangford Narrows in Northern Ireland[30]. This tidal turbine is connected to the Northern Ireland electricity grid and is currently being testing. Although this technology is in its early stages, Ireland will soon generate power from tidal resources[30].

\subsubsection{Resource}

Ireland has a significant tidal energy resource. In 2004, a study was prepared by Sustainable Energy Ireland entitled Tidal and Current Energy Resource in Ireland. The main objectives of this study were to identify the areas which have good potential for cost effective tidal electricity generation, complete a detailed analysis of the areas identified, calculate the accessible resource of tidal energy using existing technologies, and assess additional contributions which future technologies are expected to make.

The study concluded that a significant resource of tidal energy was concentrated along the east coast of Ireland and also in the Shannon estuary. After technical, physical, and accessible constrains were 
applied, the viable resource was estimated at approximately $0.915 \mathrm{TWh}$ per year[26]. The resource is also limited to areas were tidal stream velocities are $2 \mathrm{~m} / \mathrm{s}$ or greater due to current technology limitations. It was predicted that the viable resource will increase with further technology developments.

\subsubsection{Barriers}

Currently there is very little experience of electricity generation from tidal energy. The major issues restricting the use of tidal energy include:

- Technology in developing phase, with very little demonstration experience.

- Current demonstrations require the turbine to be lifted out of the water for servicing.

- Unknown environmental issues associated with power generation from tidal energy.

- Grid connection and access is not fairly provided which may cause a problem for the development of tidal energy.

- Current government support levels are considered quite low, providing a low return on capital investment.

- The taxes on renewable energy technologies reduce the competitiveness of the technology.

\subsection{Hydroelectricity}

\subsubsection{Technology status}

Hydroelectricity is the conversion of the kinetic energy in flowing water into electricity. Hydroelectricity is currently the world's most widely used renewable energy technology[31]. The potential energy of dammed water can be utilised to drive a turbine to generate electricity. There are 3 common types of hydroelectric plants including:

- Impoundment which is the most common type of hydroelectric plant. This type is considered a large hydro power plant. It uses a dam to store water in a reservoir; the water is then released through a turbine generating electricity.

- Diversion which diverts the water from a river through a canal to turn a turbine, generating electricity.

- $\quad$ Pumped Storage which pumps water from a low reservoir to a higher reservoir when electricity demand is low so that when there is high demand the water is released to generate electricity.

Hydroelectric plants range in size from large hydroelectric to micro hydroelectric plants. Large hydroelectric facilities have a capacity of $30 \mathrm{MW}$ or more. Although there are no internationally accepted capacity limits for small hydroelectric plants, the upper limit varies from $2.5 \mathrm{MW}$ to $25 \mathrm{MW}$. Micro hydroelectric plants typically refer to plants with a capacity of $2 \mathrm{MW}$ or under[32].

Advances are being made on conventional hydropower technology to reduce environmental effects. The advances in technology include:

- Using new turbine designs so that fish can more easily pass through the power plant.

- Increasing dissolved oxygen in discharges downstream of dams by autoventing turbines.

- Improving water quality with the use of re-regulating and aerating weirs to stabilise tail water discharges.

- Using adjustable speed generators to provide electricity over a wide range of heads.

- The use of instrumentation and control systems to maximise electricity production and environmental benefits.

- The use of new assessment methods to optimise the operation of reservoir systems.

\subsubsection{Market status}

Hydroelectricity is Ireland's second largest source of renewable energy electricity, after wind. As of 2006, there was an installed capacity of $528 \mathrm{MW}$ [33]. This resource is well developed and reliable. The 
development of this technology is expected to expand, with an emphasis on smaller scale hydroelectricity. Large hydroelectricity is competitive with fossil fuels, however Ireland is limited to very few large scale hydro sites for power generation. Small scale hydro has become a popular way of providing remote areas with electricity. The large scale hydroelectric plants are run by the Irish electricity supply board (ESB), and provide about $6 \%$ of Ireland's electricity[4].

\subsubsection{Resource}

There is a significant unexploited hydroelectricity resource available in Ireland at a small scale level. Ireland has a potential $71 \mathrm{MW}$ of generating capacity from small hydropower resources[32]. The majority of these sites are concentrated in mountainous areas. The amount of electricity a hydroelectric site can generate is the product of the flow volume and head[11]. The best sites having large volumes of water all year round, with a large vertical drop in a short distance. High head hydropower commonly provides the most cost effective electricity. A higher head requires less water for a given amount of power. Therefore mountainous regions have become attractive areas for cost effective electricity generation.

\subsubsection{Barriers}

The major issues restricting the development of hydroelectric plants include:

- Grid connection and access is not fairly provided which may cause a problem for the development of hydroelectricity.

- Exporting electricity to the grid over a large distance may make the project unfeasible.

- There is a lack of available sites; therefore utilising existing sites is the preferred option.

- Permissions and permits may need to be secured from planning authorities, depending on the site.

\section{Proposed Future Energy Mix for Ireland}

Ireland has excellent renewable energy resources. Although the use of renewable energy technologies has increased recently, the $1.4 \%$ of energy obtained from renewable energy sources is significantly lower than the European average of $8.5 \%$ [34]. Figure 3. illustrates the total primary energy supply by fuel in Ireland in 2006[5]. Energy supply can be defined as the delivery or transformation of fuels to the point of consumption. It potentially includes extraction, transmission, generation, distribution and storage of fuels[11].

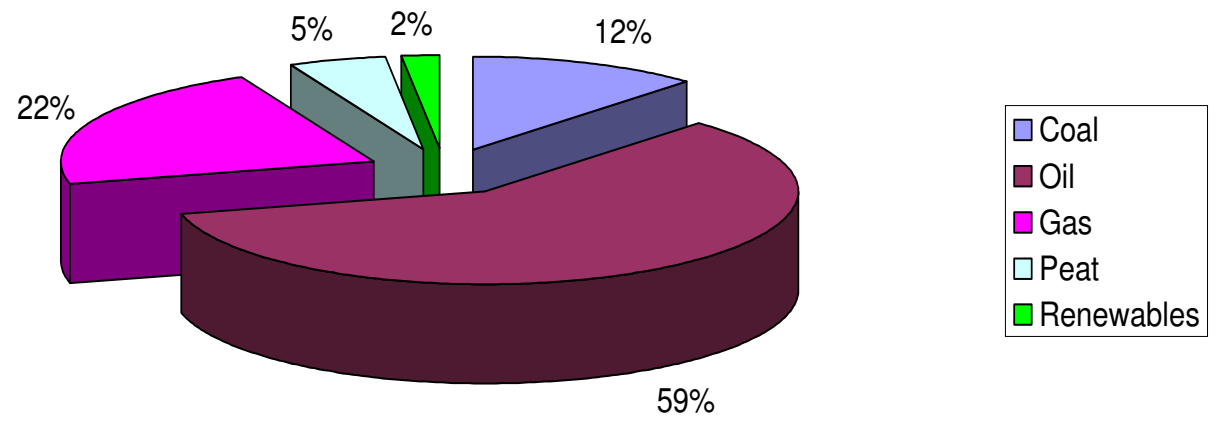

Figure 2. Total energy supply by fuel in Ireland in 2006.

This energy mix is especially concerning due to Ireland's limited indigenous fossil fuel resources. To achieve a sustainable energy supply, it is essential to increase the share of renewable energy in each energy sector. The transport sector has made very little effort to incorporate the use of renewable technologies. As of 2006, oil accounted for $100 \%$ of Ireland's transport fuel[5]. The use of oil domestically and for electricity generation has decreased due to increased use of natural gas and renewable technologies. The use of biofuel vehicles and electric motorcars are promising technologies to decrease Ireland's dependence on fossil fuels particularly oil. Coal and natural gas are primarily used to generate electricity; therefore increasing the share of renewable energy will decrease the dependence on both these fuels. Biomass could be used as a replacement for peat for electricity generation. Currently $8 \%$ of Irelands electricity is obtained from peat[4]. 
Figure 4. Illustrates a proposed energy mix for Ireland for 2020, based on Ireland's renewable energy resource:
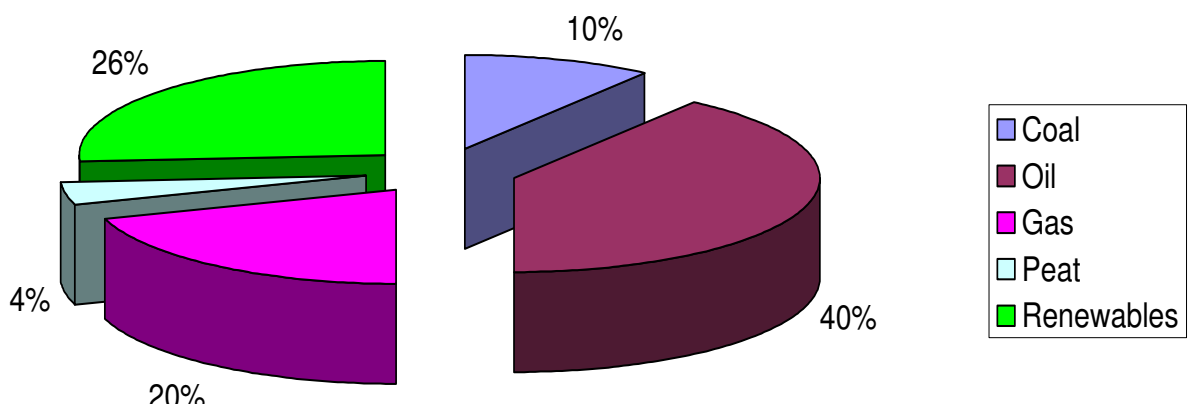

Figure 3. Proposed total energy supply by fuel in Ireland in 2020.

Electricity generation from renewable energy technologies has the greatest potential to reduce the amount of electricity generated from combusting fossil fuels. The use of renewable energy sources (wind, hydro, biomass, wave and tidal) to generate electricity could account for as much as $40 \%$ of the overall electricity supply.

The Irish government energy white paper entitled Delivering a Sustainable Energy Future for Ireland states 33\% of Ireland's electricity will come from renewable sources by 2020[5]. Since the publication of this paper there have been major advances in the development of both wave energy and tidal energy technologies. Electricity generation from wave and tidal energy technologies will soon come on stream[30]. The Irish government energy white paper sets out the aim to install at least 500MW of ocean energy technologies by 2020 , while also stating Ireland's intentions to become a world leader in research and development of ocean energy technologies.

The Irish government energy white paper also sets out the aim to achieve at least 800MW of biomass fuelled CHP by 2020. Electricity generation from wind technologies has increased significantly with an installed capacity of approximately 794.5MW[7]. Wind energy has become a popular energy source in Ireland and the technology is expected to continue growing. The Irish government energy white paper does not limit the amount of energy to be generated from renewable energy technologies.

The largest energy consumption sector in Ireland is transportation. Biofuels (indigenous or imported) could account for as much as $20 \%$ of the total transport energy supply. Financial incentives to convert private transport vehicles to biofuel will assist in reducing Ireland's oil dependence. The Irish government energy white paper also sets out a biofuels penetration target of at least $10 \%$ by 2020 . This share percentage could easily be pushed to $20 \%$ by 2020 with Ireland's excellent growth climate.

A share of $20 \%$ from renewable sources (biomass, solar and geothermal) could be integrated into the thermal energy sector. Biomass fuelled CHP could be utilised in commercial and industrial buildings. The use of geothermal energy and solar energy, especially domestically could account towards the remaining thermal energy consumption share.

\section{Conclusions}

Ireland is extremely dependant on energy imports from foreign countries. In 2006, Ireland's energy imports reached $91 \%$ of the total energy consumed in Ireland. As a result, Ireland became the most energy import dependant country in the EU. Ireland spends over $€ 7$ billion on energy each year[35]. Oil for transport is Ireland's most imported fuel. Natural gas has become the primary fuel for electricity generation with a share of $46.4 \%$ followed by coal with a share of $24.3 \%$ [36].

Comparing Ireland's energy use from 1990 to 2006, the consumption of oil has increased significantly, from 3.967 mtoe to 8.368 mtoe. In terms of total consumption the share of oil increased from $54.6 \%$ to $64.3 \%$ [36]. Natural gas consumption increased from 0.57 mtoe in 1990 to 1.567 mtoe in 2006. In terms of total consumption the share of natural gas increased from $7.8 \%$ to $12.0 \%$. As a result of increasing consumption of oil and natural gas, the consumption of coal and peat decreased from 0.843 mtoe to 0.378 mtoe and 0.757 mtoe to 0.284 mtoe respectively over the period 1990 - 2006. Energy from renewable sources also increased from 0.108 mtoe in 1990 to 0.188 mtoe in 2006[36]. 
The importation of fuels has a major impact on Ireland's economy. With regard to reducing this negative economic effect, it is imperative to increase the use of indigenous resources for electricity generation. Considering the negative impact on the environment when using fossil fuels, renewable energy sources offer minimal environmental impact.

In 2006, the use of renewable energy increased by $75 \%$ but since 1990 its overall share decreased from $1.5 \%$ to $1.4 \%$ of the final energy consumption. Renewable energy contributed $4.5 \%$ to Ireland's primary fuel mix for electricity generation in 2006[36]. The majority of Ireland's renewable energy consists of wind energy, bioenergy and hydroelectricity with an installed capacity of 794.5 MW[7], 25 MW[13] and $528 \mathrm{MW}$ [33] respectively. The use of solar energy to generate electricity is impractical due to Ireland's intermittent sunshine. This source of energy is limited to water and space heating. A recent study indicated that Ireland has significant geothermal resource; however this source is primarily utilised domestically with the use of heat pumps.

Tidal and wave energy technologies are still in their infancy; current developments in both technologies look promising. The common most important issue restricting the development of renewable energy technologies is grid access. The development of energy storage technologies will increase energy supply for times of high demand.

Ireland has commitments to meet its Kyoto Protocol greenhouse gas emissions target. To achieve sustainability and these Kyoto Protocol targets, it is essential to increase the use of renewable energy technologies. Ireland cannot continue to meet its energy demands by fossil fuels. It is essential that Ireland's energy policy sets out measures for developing renewable energy technologies. The environmental impact from the use of fossil fuels, results in several problems such as carbon tax, which lead to a decrease of the gross national product. The main aim of Ireland's policies supporting renewable energy is to increase the security of energy supply competitively while reducing greenhouse gas emissions.

\section{References}

[1] I. Government, "Delivering a Sustainable Energy Future for Ireland," 2007.

[2] B.P., "BP Statistical Review of World Energy " 2008.

[3] M. A. Ozgur, "Review of Turkey's renewable energy potential " Renewable Energy, 2007.

[4] SEI, "Energy in Ireland Key Statistics," 2008.

[5] S. E. Ireland, "Energy in Ireland 1990-2006," 2007.

[6] S. E. Ireland, "Technology of Wind Energy," 2007.

[7] S. E. Ireland, "Wind Farms in Ireland," 2007.

[8] M. a. N. R. Department of Communications, "Bioenergy Action Plan for Ireland," 2005.

[9] S. E. Ireland, "Offshore Wind Energy and Industrial Development in the Republic of Ireland," 2004.

[10] S. E. Ireland, "Wind Energy Economics, Why it pays to invest in Wind," 2006.

[11] J. T. T. Weir, Renewable Energy Resources: Taylor \& Francis, 2006.

[12] N. R. E. L. U.S., "Climate Change Technology Program. Technology Options: For the Near and Long Term. DOE/PI-0002.," 2005.

[13] M. Department of Communications and a. N. Resources, "Report on a proposed national programme to increase the gross consumption of green electricity," 2005.

[14] D. R. Authority, "Towards a Sustainable Energy Future for Ireland," 2006.

[15] E. Commission, "Biomass action plan," 2005.

[16] S. E. Ireland, "Development of Ireland's First Biomass CHP Plant," 2006.

[17] K. Kuusela, Forest Resources in Europe: Cambridge University Press, 1994.

[18] E. S. T. I. F. ESTIF, "Solar Thermal Markets in Europe, Trends and market statistics 2006," 2007. 
[19] T. E. Agency, "Solar Energy Resource Report," 2007.

[20] S. E. Ireland, "Irish Solar Energy Facts," 2003.

[21] N. R. E. Laboratory, "U.S. Climate Change Technology Program. Technology Options: For the Near and Long Term. DOE/PI-0002," 2005.

[22] A. Kagel, "The State of Geothermal technology, Surface Technology," Geothermal Energy Association for the U.S. Department of Energy 2008.

[23] S. E. Ireland, "Geothermal / Ground Source Heat Pumps," 2006.

[24] T. E. Agency, "Geothermal Energy," 2007.

[25] C. G. CSA Group, Cork Institute of Technology, "Geothermal Energy Resource Map of Ireland," Sustainable Energy Ireland 2004.

[26] M. Institute, "Ocean Energy in Ireland," Department of Communications, Marine, and Natural Resources 2005.

[27] Wavebob, "Wavebob First Irish Company to Harness Wave Power ", 2008.

[28] S. E. Ireland, "Ireland's Wave Energy Resource," 2007.

[29] OpenHydro, "OpenHydro Becomes First Tidal Energy Company to Generate Electricity onto the UK National Grid," 2008.

[30] M. C. T. Limited, "SeaGen completed: world's first megawatt-scale tidal turbine installed," 2008.

[31] I. E. Agency, "World Energy Outlook 2007," 2007.

[32] S. E. Ireland, "Hydropower," 2007.

[33] B. Griffin, "Spatial Plan for Small Hydro Development in County Cork," Cork County Council 2005.

[34] EurActiv, "The EU's Energy Mix- Aiming for Diversity," 2007.

[35] S. E. Ireland, "Five Year Plan," 2002.

[36] S. E. Ireland, "Energy in Ireland Key Statistics," 2008. 